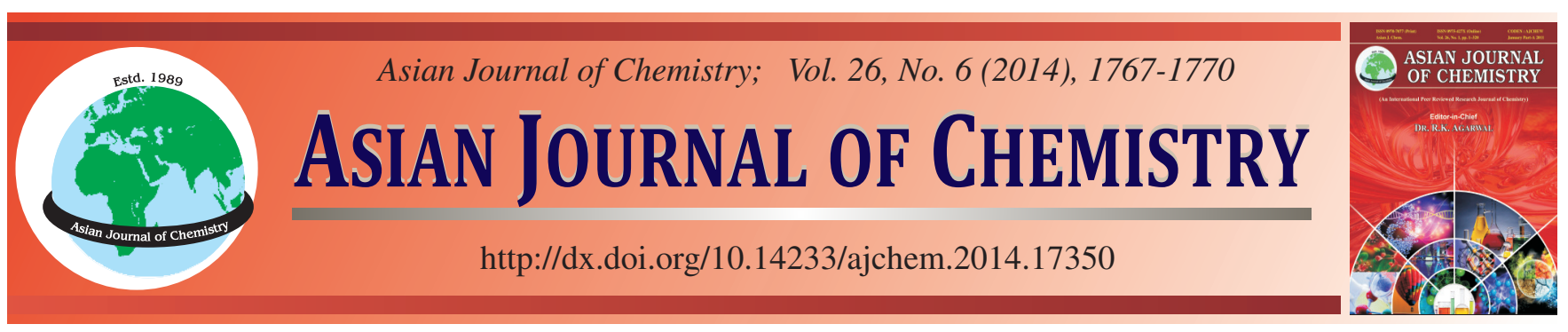

\title{
Effect of Different Current Density on the Performance of Microbial Fuel Cell and Denitrification Activity $\dagger$
}

\author{
Shaohua Chen ${ }^{1,2}$, Xuelan Xia ${ }^{3}$, Jianping $_{\text {Cheng }}^{3}$ and Jiaquan Wang ${ }^{3}, *$
}

${ }^{1}$ School of Civil and Hydraulic Engineering, Hefei University of Technology, Hefei 230009, Anhui Province, P.R. China ${ }^{2}$ College of Material and Chemical Engineering, Anhui Jianzhu University, Hefei 230022, Anhui Province, P.R. China

${ }^{3}$ School of Resource and Environment Engineering, Hefei University of Technology, Hefei 230009, Anhui Province, P.R. China

*Corresponding author: E-mail: jiaquan.wang@163.com

Published online: 10 March 2014;

AJC-14891

\begin{abstract}
A dual-chamber microbial fuel cell with nitrate as the electron acceptor had been successfully constructed. Microbial fuel cell with electricity generation (closed circuit) improved the microbial denitrification process. The effect of current density on the performance of microbial fuel cell system and its denitrification activity in the system were also investigated. The nitrate reduction rate increased along with the increase of current density. At the highest current density $\left(159.38 \mathrm{~mA} / \mathrm{m}^{2}\right)$, microbial fuel cell obtained the highest denitrifying rate $(1.83 \mathrm{mg} / \mathrm{L} /$ day $)$, max power density $\left(22.7 \mathrm{~mW} / \mathrm{m}^{2}\right)$ and coulombic efficiency $63.1 \%$. The results showed the denitrification process in the cathodic chamber was strongly depended on the electricity current generated by the microbial fuel cell.
\end{abstract}

Keywords: Microbial fuel cell, Denitrification process, External resistance, Power density, Coulombic efficiency.

\section{INTRODUCTION}

Nitrate pollution of groundwater constitutes an important and rapid increasing environmental problem ${ }^{1}$. One of the most common causes of nitrate pollution is the excessive use of fertilizers in intensive agriculture and irrigation with ammoniarich effluents discharged by wastewater treatment plants ${ }^{2}$. Conventional physico-chemical methods used to remove nitrate from water contain ion exchange, reverse osmosis and electrochemical reduction and bioremediation ${ }^{3}$. Among the techniques available for the removal of nitrate from groundwater, microbial denitrification stands out because of its economical environmental protection and being easy to a large-scale application ${ }^{4}$. Denitrification is carried out by facultative aerobic bacteria which acts as a terminal electron acceptor in respiration under the conditional absence of oxygen ${ }^{5,6}$.

Microbial fuel cells (MFCs) represent an innovative remediation technology for waste and wastewater treatment, because they have the potential for simultaneous electricity generation and removal of organic pollutants. The cathodic compartments of microbial fuel cells are less studied and in most microbial fuel cells the cathodic reaction is abiotic, typically the reduction of oxygen or ferricyanide ${ }^{7}$. In this study, we reported the results obtained from two-chambered MFCs with nitrate as the electron acceptor and MFC with electricity generation (closed circuit) improved the microbial denitrification process. The effect of current density on the performance of MFC system and the denitrification activity in the system were also investigated.

\section{EXPERIMENTAL}

Construction of two-chamber microbial fuel cell: The two-chamber MFC was constructed by connecting two plexiglas chambers $\left(15 \mathrm{~cm} \times 15 \mathrm{~cm} \times 13 \mathrm{~cm}=2925 \mathrm{~cm}^{3}\right.$ each $)$, separated by a salt bridge ( effective area of $42.7 \mathrm{~cm}^{2}$ ). Two pipes located $3 \mathrm{~cm}$ above the bottom and below the top of each chamber were set for influent and effluent streams. Carbon cloths were supplied as anode and cathode electrode material.

Experimental set-up: Solution in both anode and cathode chambers was inoculated with a microbial consortium. Anaerobic sludge was collected from Wang XiaoYing Wastewater Treatment plant.A nutrient solution $(\mathrm{pH}=7)$ contains glucose, $\mathrm{KCl}(0.13 \mathrm{~g} / \mathrm{L}), \mathrm{NaH}_{2} \mathrm{PO}_{4}(4.22 \mathrm{~g} / \mathrm{L}), \mathrm{Na}_{2} \mathrm{HPO}_{4}(2.75 \mathrm{~g} / \mathrm{L})$ and metal $(12.5 \mathrm{~mL})$ and vitamin $(5 \mathrm{~mL})$ solutions $^{8}$.

The cathodic feed consisted of the same medium, to which $1 \mathrm{~g} / \mathrm{L} \mathrm{NaHCO}_{3}$ was added as inorganic carbon source and $\mathrm{NO}_{3}{ }^{-}$

†Presented at The 7th International Conference on Multi-functional Materials and Applications, held on 22-24 November 2013, Anhui University of Science \& Technology, Huainan, Anhui Province, P.R. China 
$\mathrm{N}$ was added as the sole electron acceptor. The biotic reactor had been fed with nutrient medium and operated for several days to allow the development of microbial community.

Analysis and calculations: A subsample of each water sample was filtered $(0.4 \mu \mathrm{m})$ and analyzed for $\mathrm{NO}_{3}-\mathrm{N}$ and $\mathrm{NO}_{2}-\mathrm{N}$. Their value was determined by using Nessler-agent and ultraviolet spectrophotometry. Voltage was continuously measured by a multimeter with a data acquisition system (ADC16; Pico Technologies limited, UK) and converted to power. Power was normalized by the total surface area of the anodes. CODcr was measured according to standard methods. Total electron flow was calculated by summing the product of the time interval and the current passed through the circuit. Coulombic efficiency was calculated as the total coulombs measured divided by the moles of CODcr removed assuming $4 \mathrm{~mol}$ of electrons/mol of CODcr.

\section{RESULTS AND DISCUSSION}

Microbial fuel cell performance under closed/open circuit: To investigate whether electricity generation affects the denitrification process or not, at the first $107 \mathrm{~h}$, the MFC operated at an open circuit and then at an closed circuit with external resistance $30 \Omega$. The profile of $\mathrm{NO}_{3}-\mathrm{N}$ and $\mathrm{NO}_{2}-\mathrm{N}$ concentration in the cathodic chamber of the MFC was presented in Fig. 1.

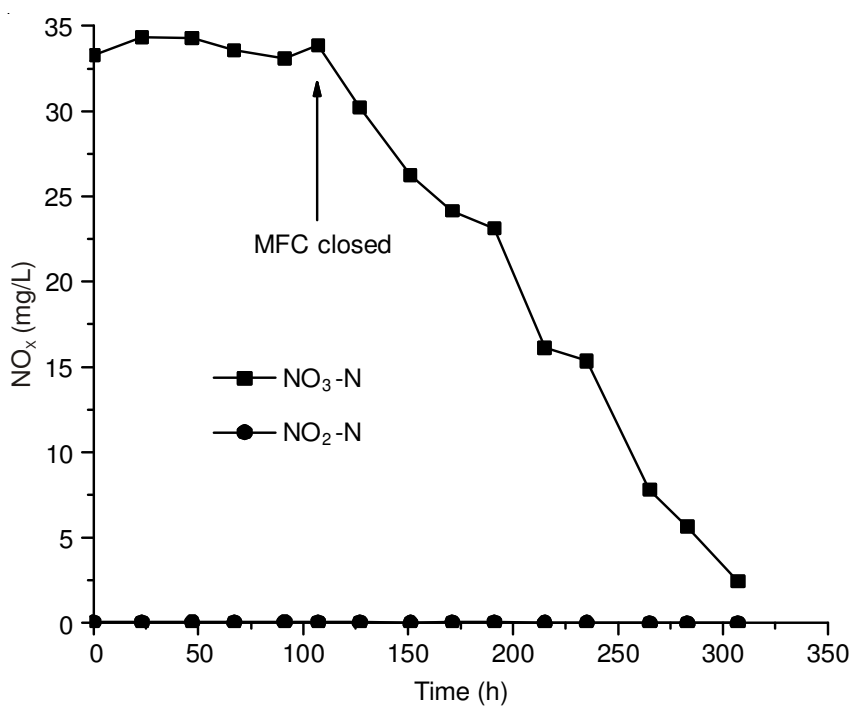

Fig. 1. Variations of $\mathrm{NO}_{3}-\mathrm{N}$ and $\mathrm{NO}_{2}-\mathrm{N}$ concentration in the cathodic chamber of MFC (closed circuit) and control MFC (open circuit)

The result showed that $\mathrm{NO}_{3}-\mathrm{N}$ concentration restarted to decrease from 33.9 to $2.44 \mathrm{mg} / \mathrm{L}$, which demonstrated that MFC could improve the denitrification process. Electrons extracted from glucose in the anode flew to the cathode through an external circuit and subsequently were transferred to nitrate via biological catalysis, resulting in nitrate reduction. It was just improved by further $\mathrm{NO}_{3}-\mathrm{N}$ decreasing at a rate of 3.75 $\mathrm{mg} / \mathrm{L}$ per day. These results also suggested that biocatalyst could accept electrons to reduce $\mathrm{NO}_{3}-\mathrm{N}$. The $\mathrm{NO}_{2}-\mathrm{N}$ concentration of MFC was very low during the whole period.

The removal of nitrate from wastewater was faster in the MFC with electricity generation (closed circuit) than in the same type of MFC with an open circuit. It improved the denitrification process probably due to its special electrochemical system.

The average output voltage in the MFC was $25 \mathrm{mV}$ with external resistance $30 \Omega$. The maximum power density obtained was $6.89 \mathrm{~mW} / \mathrm{m}^{2}$ with a current of $0.47 \mathrm{~mA}$ by varying the circuit resistance from 20 to $7000 \Omega$. Based on the polarization curve and relation $R_{\text {int }}=-\Delta V / \Delta I$, the internal resistance was estimated at $233.7 \Omega$. Coulombic efficiency of the system, based on CODcr removal and current generation, was $95 \%$ indicating a substantial fraction of the organic matter was lost without current generation.

Two closed circuit MFCs were constructed to investigate the effect of a microbial consortium on the denitrification process. The results were presented in Fig. 2.

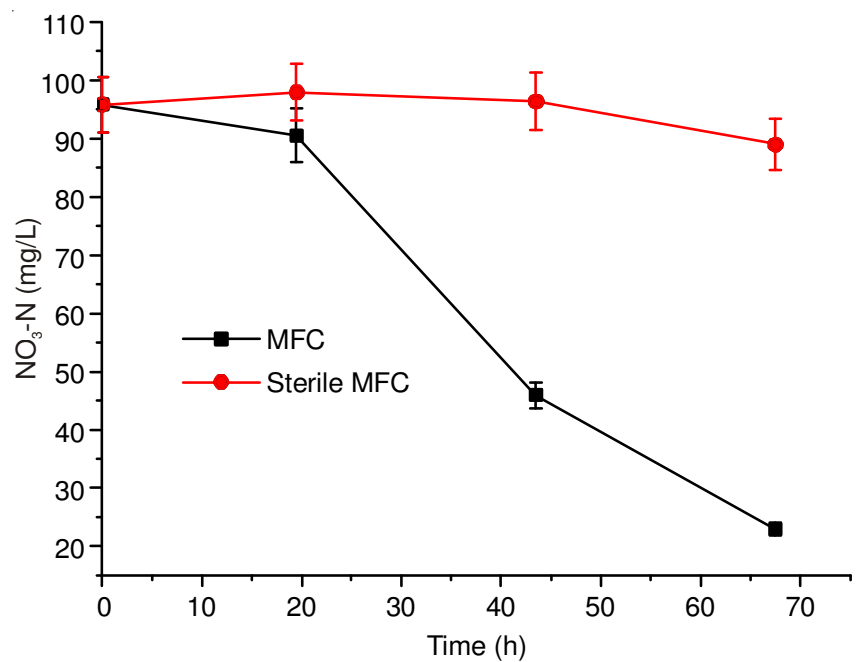

Fig. 2. Variations of $\mathrm{NO}_{3}-\mathrm{N}$ concentrations in the cathodic chamber of MFC and sterile MFC

As seen from Fig. 2, the degradation rate of nitrate concentration decreased in the MFC and sterile MFC by $76 \%$ (from 95.81 to 22.88 ) and $7 \%$ (from 95.81 to 89.01 ), respectively during the experiment period. The per cent of initial $\mathrm{NO}_{3}-\mathrm{N}$ remaining in the cathode chambers of the MFC was significantly lower than in the sterile MFC. The significantly larger decrease in $\mathrm{NO}_{3}-\mathrm{N}$ in the MFC with a microbial population in the cathode chamber compared to sterile MFC demonstrated that the presence of bacteria enhanced nitrate reduction. The slightly decrease of $\mathrm{NO}_{3}-\mathrm{N}$ in the sterile MFC suggested that electrons were directly to $\mathrm{NO}_{3}-\mathrm{N}$ with no microbial intermediary.

Effect of current density on microbial fuel cell nitrification rate: To better simulate the operation mode of the groundwater, the cathode was feed on a flow mode with 13 $\mathrm{mL} / \mathrm{min}$ of the cathodic influent and the MFC operated at three different current densities varied by external resistances (100, $187,1000 \Omega$ ). The profiles of $\mathrm{NO}_{\mathrm{x}}-\mathrm{N}$ concentrations in the cathodic chamber of MFC with different external resistances were presented in Fig. 3.

Fig. 3 showed $\mathrm{NO}_{3}-\mathrm{N}$ concentration decreased with an in crease of $\mathrm{NO}_{2}-\mathrm{N}$ and $\mathrm{NH}_{4}-\mathrm{N}$ in MFC with different external resistances. The output nitrate concentration decreased at $100,187,1000 \Omega$ from 32.2 to 4.2 ( $1.56 \mathrm{mg} / \mathrm{L} /$ day $), 32.8$ to 0.55 ( $1.83 \mathrm{mg} / \mathrm{L} /$ day $)$ and 32.6 to 28.0 (0.30 mg/L/day), 


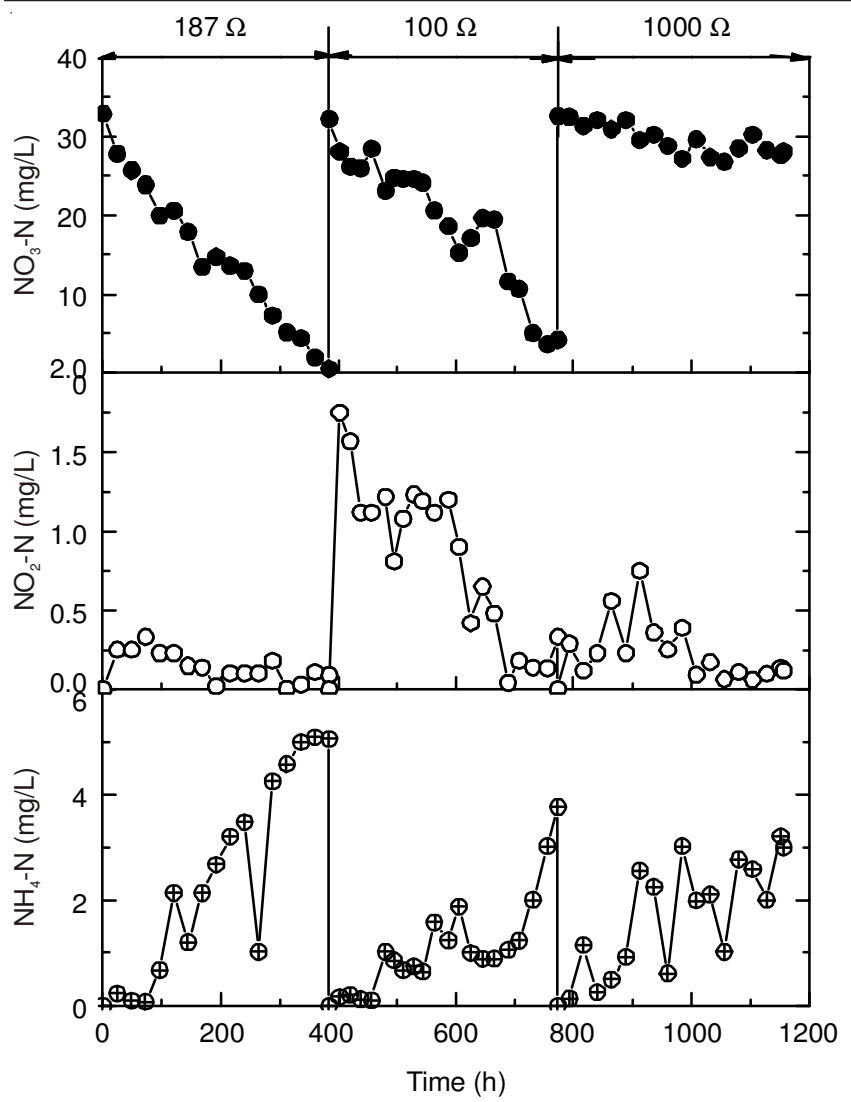

Fig. 3. Variations of $\mathrm{NO}_{3}-\mathrm{NNO}_{2}-\mathrm{N}$ and $\mathrm{NH}_{4}-\mathrm{N}$ concentrations in the cathodic chamber of MFC under different external resistance (100, 187 and $1000 \Omega$ )

respectively. At the end of the each batch experiment, nitrate concentrations were less than $5 \mathrm{mg} / \mathrm{L}$ at 187 and $100 \Omega$. The nitrate concentrations at $1000 \Omega$ were almost invariable. The denitrification rate at $187 \Omega$ was higher than those at 100 and $1000 \Omega$. The results demonstrated that the denitrification rates were greatly affected by the external resistance.

The nitrite concentrations of MFC with different resistances increased at first and then almost decreased to zero. These results were in agreement with those obtained by Brylev et al. ${ }^{9}$, which proved nitrite was an intermediate product during nitrate reduction and it was probably further reduced to nitrogen gas or ammonia; or oxidized into nitrate again. The highest amount accumulation of nitrite were $1.75,0.33$ and 0.75 $\mathrm{mg} / \mathrm{L}$ at 100, 187 and $1000 \Omega$, respectively. On the other hand, ammonia concentrations of MFC increased from 0 to 3.77 , 5.06 and $3.22 \mathrm{mg} / \mathrm{L}$, respectively.

Effect of external resistance on voltage and power density: The cell voltage of MFC gradually increased when adding the glucose. As the glucose in the anodic chamber was consumed by the microbial oxidation, the cell voltage was also decreased. When refreshing mediums were added during the experiment, the voltage recovered and reached its maximum value immediately.

Results suggested that power generation in these MFCs was primarily due to direct electron transfer by bacteria attached to the electrode and not suspended bacteria or bacteria producing mediators in the biofilm.

It was found over time that the maximum current densities here were $159.38 \mathrm{~mA} / \mathrm{m}^{2}(187 \Omega), 143.75 \mathrm{~mA} / \mathrm{m}^{2}(100 \Omega)$ and
$40.63 \mathrm{~mA} / \mathrm{m}^{2}$ (1000 $\Omega$ ). It could be seen from Figs. 4 and 5 that the highest nitrate reduction rate was obtained at a current density of $159.38 \mathrm{~mA} / \mathrm{m}^{2}$, while that was the lowest at a current density of $40.63 \mathrm{~mA} / \mathrm{m}^{2}$. The nitrate reduction rate increased with increasing current density from $40.63,143.75$ and 159.38 $\mathrm{mA} / \mathrm{m}^{2}$. Due to the highest resistance, the lowest nitrate reduction rate was obtained in the cathodic chamber, which resulted in low cell current. Higher current density was obtained, more electrons were transfered from anode to cathode where microorganism accepted electrons to reduce nitrate. The results also showed that MFC at a current density of $159.38 \mathrm{~mA} / \mathrm{m}^{2}$ had the high selectivity of nitrate reduction to ammomia and very low concentration of nitrite has been detected in the cathodic solution.

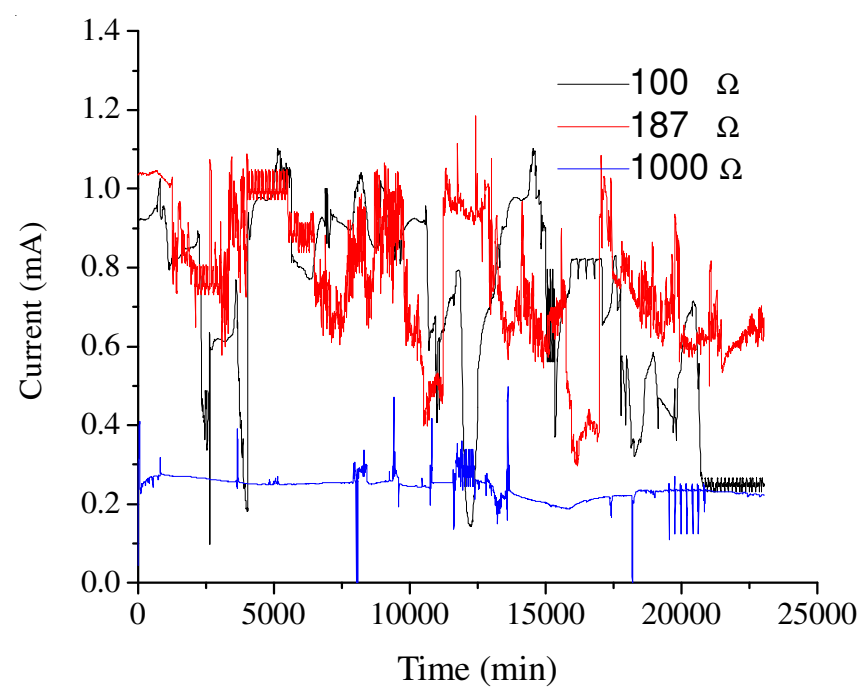

Fig. 4. Variations of current generation in the cathodic chamber of MFC under different external resistance $(100,187$ and $1000 \Omega)$

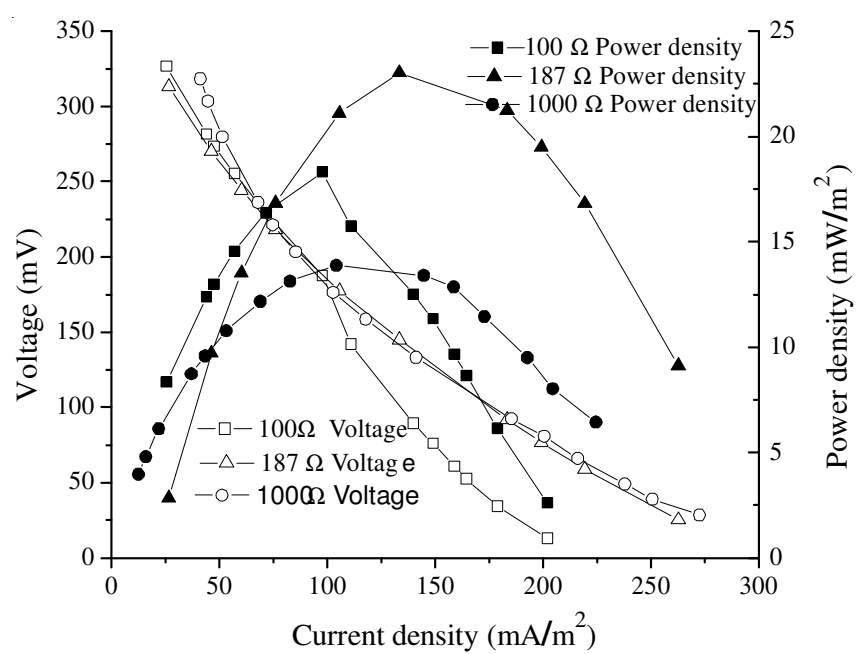

Fig. 5. Polarization curves of MFC under different current densities (100, 187 and $1000 \Omega$ )

\section{Conclusion}

Anoxic-cathode MFCs were successfully developed in the present study. Microbial fuel cell with electricity generation (closed circuit) improved the microbial denitrification process. The nitrate reduction rate increased with increasing current density. At a highest current density of $159.38 \mathrm{~mA} / \mathrm{m}^{2}, \mathrm{MFC}$ 
obtained highest nitrification rate $1.83 \mathrm{mg} / \mathrm{L} /$ day, power density $22.7 \mathrm{~mW} / \mathrm{m}^{2}$, coulombic efficiency $63.1 \%$. Denitrification in the cathodic chamber was affected strongly by the current density and depended on the electricity current.

\section{ACKNOWLEDGEMENTS}

This work was financially supported by the National Science Foundation of China (No.41372246), the PhD Startup Found of Anhui Jianzhu University (No. K02644) and National College Science and Technology Creation Project (No. 201310878013).

\section{REFERENCES}

1. H. Park, D.K. Kim, Y.J. Choi and D. Pak, Process Biochem., 40, 3383 (2005).

2. O. Brylev, M. Sarrazin, L. Roué and D. Bélanger, Electrochim. Acta, 52, 6237 (2007).

3. J.M. Tront, J.D. Fortner, M. Plotze, J.B. Hughes and A.M. Puzrin, Biotechnol. Lett., 30, 1385 (2008).

4. P.J. Sturman, P.S. Stewart, A.B. Cunningham, E.J. Bouwer and J.H. Wolfram, Hydrol., 19, 171 (1995).

5. W.J. Payne, Denitrification, Wiley, New York (1981).

6. J.M. Morris and S. Jin, Chem. Eng. J., 153, 127 (2009).

7. S. Freguia, S. Tsujimura and K.J. Kano, Electrochim. Acta, 55, 813 (2010).

8. M. Kuroda, T. Watanabe and Y. Umedu, Water Sci. Technol., 34, 101 (1996).

9. R.A. Rozendal, H.V.M. Hamelers and C.J.N. Buisman, Environ. Sci. Technol., 40, 5206 (2006) 